\title{
Different roles in the quest for system resilience
}

\author{
Fábio Morais Borges ${ }^{\mathrm{a}, *}$, Nilton Luiz Menegon ${ }^{\mathrm{b}}$ \\ ${ }^{a}$ Department of Industrial Engeneering, University of Paraiba, Campus Universitário I, CEP: 58051-900, João \\ Pessoa, Brazil \\ ${ }^{\mathrm{b}}$ Department of Industrial Engeneering, University of São Carlos, menegon@dep.ufsca.br, São Carlos, Brazil
}

\begin{abstract}
Into dangerous and complex systems with high degree of interactivity between its components, the variability is present at all time, demanding a high degree of control of its operation. Maintaining or recovering the normality, when the system is under some stress (instability) is a function of Resilience. To cope with prevention, forecast, recovery and with memory of experiences from learned lessons requires some features from the companies. This paper purposes a structure that enables the Total Resilience of a system production that defines the assignments for Workers, Designers and Management Team, according to its features and possibilities. During one year and a half developing studies on ergonomics area of a Brazilian Oil Refinery, several situations were observed and studied using Work Ergonomic Analysis. These situations show actions and strategies that workers use to maintain the system stability. Furthermore, they revealed the importance that these actions are stored in a database of learned lessons from the Company. The research resulted in a broad scheme. It places each of these groups in the process of Total Resilience. It also shows the human like a center of actions that ensure the continuity of the system, main element at Resilience (Anthropocentric View).
\end{abstract}

Keywords: resilience, management, designers, workers

\section{Introduction}

In complex systems with a high degree of interactivity between their components, variability is present at all times making these systems highly dynamic and demanding a high degree of control of operation. In the case of production systems with high level of risk, complexity is increased and dynamism is enhanced, and the need for control increases in the same proportion. This is what happens in nuclear power plants, air traffic control, steel mills, emergency medical services, and refineries.

As the risk associated with unexpected situations within these systems increases, the response time to the event decreases.Hence, one of the most unfavorable scenarios is created: unusual events, sometimes unprecedented, with potentially devastating consequences and very little time to restore the system operational stability.That is acritical situation,when the worker must deal with all regulations involved in the activity, his/her personal variability, and the goals to be accomplishedin order to make a decision.

The intervention in the event of system instability, most often, should be fast, if not even immediate. Thus, Resilience- ability to respond to an unusual or unexpected event, under pressure, and be successful $[21,41,30]$ - can be more effectively ensured by workers. Since they are in direct contact with the system and have a better understanding of its evolution, they are able to intervene more quickly than the management team when necessary.

The management team and the designers have a limited view of the system, which omits or even denies unplanned situations. Therefore, any emergency action taken by those responsible for the system management is based on precepts, procedures, rules, and static models, thus being less effective than it is credited with.

Since the worker, is continuouslycreating the problem he must solve[39] and performinga permanent risk management [20], he/she should be the person

*E-mail: fabiomoraisb@ct.ufpb.br 
to respond immediately to changes in the system. Frequently, the worker does so by breaking precepts. Violating those procedures indicates an intelligent adaptation to the demands in work situations [1].

Based on the discussion presented, the objective of this study is to consider the workers as the central elementsto perform the actionsfor system resilienceand stimulate them to provide important information regarding the designs, specially,onsystem resilience. Two other groups of actors involved in the process design also have important roles in the quest for totalsystem resilience:the management team and the designers.

\section{Resilience}

Borrowed from other areas such as physics and materials science, the concept of resilience,regarding production systems, carries a connotation related to reliability. Studies in this area have associated resilience capacity with workers more frequently than with machines and equipment. This is what differentiatesresilience from technical reliability; which is more closely related to the parts lifetime and the study of component failures.

Even without a unanimous definition in the literature,resilience can be characterized in two different ways. The first defines resilience as the ability to manage the activities of a company to maintain or recover the system stabilityquickly allowing it to continue operations during and after an incident or a mishap $[21,31,42,30]$.The second is related to the inextricably linked trade-off between production and safety goals. According to this definition, resilience would be the ability to balance considerable pressure and conflicts between the company safety and performance goals or its primary production goals [23.13].

The Models of Probabilistic Safety Analysis assess the likelihood of human errorsthrough fault trees analysis or failure logicfocusing on the types of errors and events that may lead to potential accidents. On the other hand, Resilience is focused on the worker activity searching for elements to analyze reliability, especiallythose of strategies and response actions to events.Considering the variability involved (intra-and interpersonal) as inextinguishable and finding ways to deal efficiently with them.Resiliency also includes a set of concepts that defines, more precisely, the reality of the facts and the relationship between the various components that interact in coordinated work.

All those involved in the system have a role in the quest for resilience. Groups that have the same features should be continuously activated and assume their responsibility. Dealing with prevention, prediction, recovering, and the building of memory from lessons learned, requires that the company should have a systemic and holistic view on human reliability instead of focusing only on the workers' actions at the time of an incident in order to ensure resilience.

\section{Total Resilience}

The gap between the work as designed and the way it is actually done presents a difficulty forthe management team in dealing with risks in real situations. In fact, workers are able to accomplish those tasks more effectively since they are the first to notice system instabilities and should immediately make a decision that will define the actions to be taken thereafter.

The management team, sometimes, is not even aware of the number of inconsistencies and errors that affect a production system. Nevertheless, those who manage the system are responsible for making appropriate changes to worker actions to incorporate the lessons learned.

Designers have a similar role. Since they are responsible for designing new systems, these actions should be incorporated in the design process thusensuring a resilient design. The process must be complete encompassing all levels of business (operational to strategic).

The overall process, including the event that causes system instability, the immediate actions the workertakesto reestablish normal operation, and the changesmadeto actions, by the management team, in order to incorporate the lessons learnedcan be seen in Figure 1. In addition, close attention should be given,by the designers, to the incorporation of the strategies the workersusewhen they face such instabilities.Furthermore, every device, and equipment design as well as other means of production must take into account not only the lessons learned, but also the causes that led to the initial instabilities. 


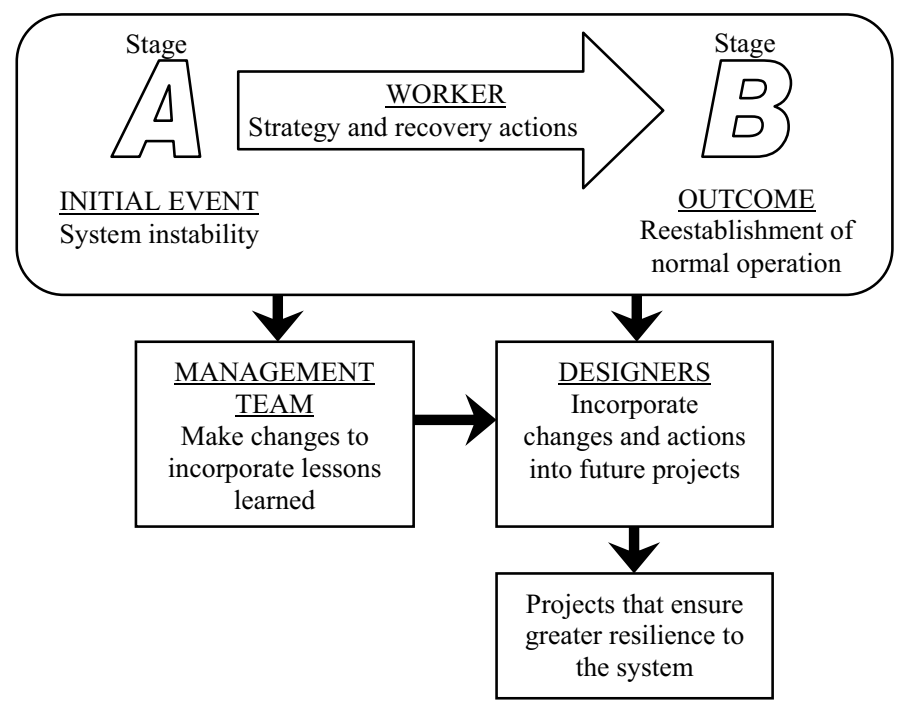

Fig.1 - Features that ensure the total Resilience of a production system

Regularly, the strategies employed by employees workersin continuous process industries-are related withanticipation and prediction. Through the perception of the evolution of the system, the workers know what will happen and take actions in order to avoid any unintended consequence. They use new savoirfaireand new individual and collective strategies to prevent the occurrence of incidents or accidents. These strategies have a key role in the reliability of organizations and the industrial systems' operation [20.34].

However, in order for this action to be complete, the lessons learned have to be properlystored and should be available and easily accessible to the designers; after all, the major purpose of this dynamics is to prevent the reoccurrence of unwanted events. The conception should be based on the principles of continuous improvement. Therefore, the occurrence of problems that had been detected earlier, which, very often, had been solved and proven effective, is unacceptable.

More than making changes to actions to incorporate the lessons learned, managers should addthe precepts of Resilienceto their decisions and plans. Decisions regarding the acquisition policies of a company can significantly affect the reliability of a system. Additionally,according to [2], reducing the technological advancement pace should facilitate risk assessment and manage the risks efficiently avoiding the unequal distribution of risk between workers and decision makers. The management level has great influence on risk management. This becomes even more evident when [30] states that in complex systems minor incidents are frequent and are due in great part to the great variability of technical systems and those thatdesign them.

Managers are not the only ones who should seek to reduce the gap between the designed and actual work. System designers should incorporate the strategies and actions the workers use into the design in order to ensure system reliability. Although overlooked by some people, designers also face constraints that often prevent them to consider aspects that can facilitate the interaction between worker and tasksduringthe design of the system, which frequently results inattributing responsibility for this distance solely to the designers.

Understanding how the work is done by observing activities, is an essential factor for a conception that focuses more on the needs of workers. According to [8], even being pre-existing, the rules can only be applied when activated in the temporality of actions and its discovery can only occur by means of an observer who detects its at the time they occur. Therefore, the relationship between the designer and workersshould be as close as possible since work activities reproduce the design.

Inconsistencies between the work as designed and the way it is actually doneare reducedwhenthe workers are included in the design process. Since the mid- 
60s, the European Coal and Steel Community (ECSC), have adopted the idea that production and safety should be designed based on the workers, their operation, and their work activity, and not on the opposite [25]. This also applies to the issues related to Resilience. Since workersare the first to have contact with instabilities, they become key elements in the design of more resilient systems. Therefore, besides being fundamental to ensuring and maintainingthe system reliability, theyshould effectively participate in the system design.

\section{The Role of Workers}

Two important roles of workers in ensuring the system reliability can be highlighted. The first is related to their ability to adapt to the differences between the work as designed and the way it can be effectively done. Secondly, the workers should to take part in the design process as experts who have important information about the tasks and the activities they undertake.

According to [26], very often, the scenario of the task should be extended since the worker has to find information that is not included in the design plan. This sustains the vital role of the workerinresolving the inconsistencies of the system designdue to the dynamism and complexity of the routine events of a production system

Due to the fact thatthe workers are the closest ones tothe production system, they are also the first - in most cases - to become aware of possible instabilities and errors.The quality and speed with which they respond to these events can distinguish between recoveringthe system stability or atotal loss of control. The ability of an organization to adapt to new or complex problems without disrupting the operation of the system - its resilience - is directly linked to the ability of workers, at the operational level,to make important decisions without having to wait unnecessarily for management instructions [42].

This author presents an example in the case of changes -which mayseem subtle to those who are inexperienced - in medical surgical procedures. Sometimes, the medical team hasto change the initial procedure to add other protocols and adopt a strategy to respond to a crisis due to complications in the patient's vital signs. This is something that would be considered a human error by traditional safety analysis since it deviates from the pre-established procedures. However, this demonstrates the ability to adapt and the sense of anticipation of the work-
er.Asexplained by [20], the requirements and procedures are necessary but not sufficient, since they can not anticipate every situation (situation normal and incidental). The effectiveness of decision making is, according to [4], directly related to the competence of the worker, the quality of information obtained from the system, and theways of obtaining information.This becomes even more explicit in complex systems such as refineries. Several factors indicate that the workeris the main element for system stability considering the monitoring and maintenance of normal operations and the recovery, when something interferes with the continuity of production processes. Extensive research on this type of systemhas shown that the workers use "feeling" [17]. This feeling is certainly grounded on earlier life experiences and theknowledgeacquired by each person. It is not intuitive; it is reasoned.It is an internalized knowledge, which,when processed efficiently, enables human beings to carry out strategies and take effective actions.

An example is the case reported by a laboratory technician in a refining unit of the Brazilian'slargest oil company. The calibration of an analyzer - equipment used to analyze samples of naphtha, gasoline, toluene, and benzene - required even more information than that provided in the equipment manual, according to the technician. He said "when we had to calibrate the equipment, we lookedin the manual at the error messages description. We tried hard to follow the information, but we could not put it into operation". The device sucks the sample through one side, performs the analysis, and ejects the sample through the opposite side (Figure 2).

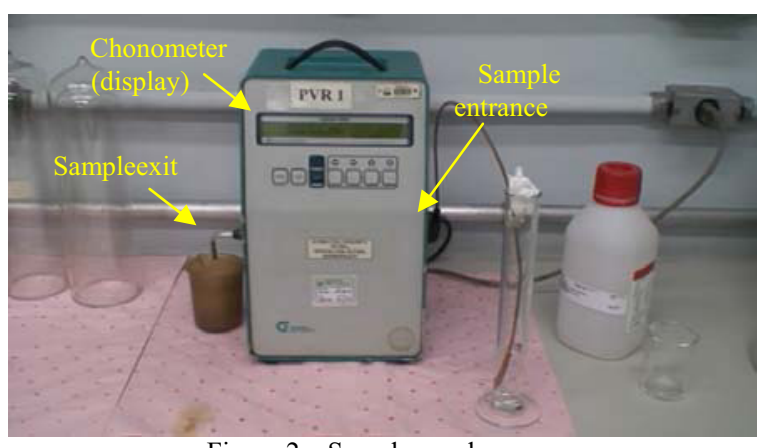

Figure 2 - Samples analyser

The problem detected by the technician was that the piston that sucks and ejects and the sample, inside the equipment, would start workingunsynchronized with the chronometer (display), which indicates the time of suction and ejection. This could interfere in 
the values being measured. In order to ensure accuracy, the technician decided to focuson the sound emitted by the piston when it started working, by timing it manually. He reported the strategy he adopted intuitively: "From the sound emitted by the piston, I knewit was moving upward and downward". Something that may seem irrelevant, but this very simple act, means a great deal of knowledge acquired at work and put into action.

This kind of knowledge is used every day at work, even if not always formalized, expressed, and recognized [22]. Like the indicators that depend on the perception and sensory organs (smell, hearing, etc.), which are more subjective and that relate to the experience of people, they are as important or even more important than the formal indicators[17].

Even the activities considered manual or those that seem simple, require a considerable and irreplaceable mental effort from the workerto ensure the operation of the production system [18].Corroborating this statement, [5] argues that the simplicity of worker's hand gestureshides the complexity of the cognitive actions that ensure the continuity of the production process.This describes one of the major roles of humans in promoting resilience of a system and maintaining its reliability. They integrate the initial information about the action and build maximum certainty scenariosto cope with uncertainty.

A second role of workers in promoting resilience is their participation in the sytemdesign. Ergonomics - as well as other areas - has drawn attention to the importance of participation of workers in the process of designingwork settings not only as evaluatorsor to have their knowledge expropriated, but also as an active participant together with other actors in this process $[27,14,35,9,3,19]$. Not taking into account the activity as it is performed with all the constraints and limitations to which theworkers are exposed, creates a gap between the design and the real conditions the tasks are undertaken and the needs of the workers. This gap between real activities [...] and the dominant representations that guide the system designers appears to be the major cause of ineffective or dangerous design of the means of production [19].

In addition to includingthe requirements that the activity demands from the worker to the discussion aboutthe design, incorporating the worker in the design process allows the addition of the expertise theyacquired in carrying out activities. This also includes the actions and strategies to ensure the resilience of the system.

The lessons learned are the result of a process that begins with a temporary or permanent instability in the production system. The most important part of this entire process is focused on the worker. Conditions that allow proper collection and processing of the system information, facilitating decision-making, should be incorporated into thedesign. No one is better prepared to assist in this process than the worker. Thisdoes not imply in a simple replacement of workersfor automata. It is necessary to provide adequate conditions for those actions and strategies to achieve formalized and structured resilience. Herein lies an important principle, that of optimization. According to which, it is a human beingwho decides whether the system is working properly and, above all, if it could work betterby assigning values and principles of assessment or effectiveness to the operation of the technical system [28]. These authors also argue that besides being responsible for keeping the system running, workers should provide information to the designers focusing on the improvement of the system.

\section{Conclusion}

The role of each actor within a production system in the questfor resilience, as shown above, should be focused on preventive measures. Some paradigms should be broken and other concepts, which have already been accepted,should be more widespread and actually made operational.

The path shown in Figure 1 involves management decisions and change of view from those directly involved with the system design process, besides challenging experts to build effective systems to storethe lessons learned. Improvements in one of these stages are important, but they should not occur isolated due to the risk of not achieving a high level of resilience by attacking only one of these pillars: management team, designers, or workers. They must undertake joint actions, and the system evolution should be global, even if it is slow, to assure maturity levels of resilience.

Guiding policies and plans to increase the organization'sability to adapt to instabilitiesmight be one the most complex approaches. This reflects the old discussion of productivity gains due to the increased reliability of the system and questions the paradox for many, unreachable - that safetyimprovement can lead to productivity gains; including both personal and the production system safety.

Making the management team - those who are more distant, sometimes even physically, - aware of their role in ensuring resilience in the organization is not an easy task. Choosing between own or out- 
sourced production and effective policies to reduce costs effectively, planning production goals, and deciding on the technology to be employed in the production system may have beneficial or disastrous consequences in terms of adaption ability. This concern has been widely discussed in several studies $[21,33,23,5,37]$.

Another challenge in the quest for resilience of the system involves changes in the deterministic view, still a much solidified, that assumes design as a topdown activity. The opening of the process and the design teams will not effectively occuruntil the designers understand that the social making of the design [7.29] and a collaborative design [6,16,32] are the most appropriate conceptions in accordance with the characteristics that are really necessary in the activity. This is not just a matter of including other people rather than the designers in the choices and decisions about the system design. It involves issues of control, hierarchy, and even vanity.

It is worth highlighting that the designer also faces several limiting constraints such asconstraints of time, space, resources, internal conflicts, organizational conflicts, sudden changes in the market, issues of standardization, culture issues, etc; in sum, a wide range of factors that restrict ideas and solutions. Thedesigner activity should be seen as any other work activity, according to the Ergonomics concepts - constraints, operational methods, regulatory space, intra and interpersonal variations- since it has also beeninvestigated by ergonomists, as seen in some studies $[10,14,3,19]$. It is necessary to increase the freedom of action of those involved in the system design by providing adequate conditions for the use of regulatory strategies in the face of constraints, according to the precepts of ergonomics [12,38,11,24].

A collaborative process should take place at the design level including the participation of workers in all stages of this process. Special attention should be given to the initial stages, in which the empirical knowledge of those who deal daily with work situations, may favor a more resilient design without impacting negatively the cost of the design. In addition, it would allow for possible modifications in the initial stages; this scenario becomes unfavorable as the design progresses.

It is always important to mentionthe use of the lessons learned, provided by management team, fromthe strategies and actions of workers in response to system instabilities. The more appropriate to the design activity those set of lessons are, the better they can be used by the design team. In order to be effective, the information about these lessons as well as theway of obtaining such information must be in accordance with the design activity.

Humans should be seen as the main elements for total resilience when considering the actions that assure the continuity of the system. There are several factors that favor this statement: their deep knowledge of the system including its deficiencies, redundancies, and shortcuts; they are those who are,in most cases, closer to where the instabilities occur;and they areable to adapt to different situations by using Situation Awareness [15] to anticipate undesirable events through the evolution of the system indicators organizingmentally the solution to certainproblems before presenting them thus increasing the stability of the system [36].

People can also correct some deficiencies in the technical system. According to studies on control of continuous processes, [28] statethat usually the alarms go off too late, and therefore workers will become responsible for avoiding crashes in the system. The technical system often works with tolerance limits, and the system response is only given if something disrupts its normal operation. However, the transition from normal state to loss of control can be extremely rapid and the response time to an unforeseen event may not be enough. Hence, this emphasizes the importance of humans in monitoring the systemby acting, if necessary, before the system response. Studies carried out by Cook and O'Connor evaluating a medical service showed that the resilience of the system resides in its people rather than in its technology [40].

The definition of the roles of these three groups of actors, who are involved in some way in the design process, contributes to ensure the total resilience of the system. Implementing these roles requires some challenges involving conceptual and cultural changes including both personal and organizational changes.

\section{References}

[1] AMALBERTI, René. Da gestão dos erros à gestão dos riscos. In: FALZON, Pierre (Org.). Ergonomia. São Paulo: EdgardBlücher, 2007

[2] ASSUNÇÃO, Ada Ávila; LIMA, Francisco de Paula Antunes. A nocividade no trabalho: contribuição da ergonomia. In: MENDES, René. Patologia do trabalho. São Paulo: Atheneu, 2003.

[3] BÉGUIN, Pascal; DARSES, Françoise. Les concepteurs au travail et la conception des systèmes de travail: points de vue et débats. In: Communication au ColloqueDeuxièmejournéesRechercheetErgonomie, 1998.

[4] BORGES, Fábio Morais; MENEGON, Nilton Luiz. Fator humano: confiabilidade às instabilidades do sistema de 
produção. In: Simpósio de engenharia de produção, 16, 2009 , Bauru. Anais... Bauru, 2009

[5] BOUYER, Gilbert Cardoso; SZNELWAR, Laerte Idal. Análise cognitiva do processo de trabalho em Sistemas Complexos de Operações. Ciências\&Cognição, 4, 2005

[6] BROMBERG, Olé. Quando o projeto participativo de espaços de trabalho se encontra com o projeto de engenharia em eventos de colaboração mútua. Laboreal, 4, (2), 2008.

[7] BUCCIARELLI, Louis L. Engineering philosophy. Amsterdam: IOS Press, 2003.

[8] COULON, Alain. Etnometodologia e educação. Petrópolis: Vozes, 1995

[9] DANIELLOU, François. A ergonomia na condução de projetos de concepção de sistemas de trabalho. In: FALZON, Pierre. Aergonomia. São Paulo, EditoraBlücher: 2007

[10]DARSES, Françoise. Résolution collective des problèmes de conception. Le travail humain, 72, (1), 2009.

[11]DE KEYSER, Veronique. Work analysis in French language ergonomics: origin and current research trends. Ergonomics, 34, (6). Oxford: 1991.

[12]DEJOURS, Christophe. Subjetividade, trabalho e ação. RevistaProdução, 14, (3), São Paulo: 2004

[13]DEKKER, Sidney. Resilience Engineering: Chronicling the emergence of confused consensus. In: HOLLNAGEL, Erik; WOODS, David D.; LEVERSON, Nancy (Org.). Resilience engineering: concepts and precepts. Aldershot: Ashgate, 2006

[14]DUARTE, Francisco; CONCEIÇÃO, Carolina, CORDEIRO, Cláudia; LIMA, Francisco. A integração das necessidades de usuários e projetistas como fonte de inovação para o projeto. Laboreal, 4, (2), 2008, pp. 62-74

[15] ENDSLEY, Mica R. Situation awareness. In: KARWOWSKI, Waldemar. International encyclopedia of ergonomics and human factors. 2ed. Boca Raiton: Taylor \& Francis Group, 2006.

[16]FALZON, Pierre; DARSES, Françoise; SAUVAGNAC, Catherine. Une perspective ergonomiquesur la construction etl'évolution des savoirs experts. In: L'ergonomiaet les sciences cognitives. Actes des JournéesRecherche et Ergonomie Toulouse: 1998

[17]FERREIRA, Leda Leal; IGUTI, Aparecida Mari. O trabalho dos petroleiros: perigoso, complexo, contínuo e coletivo. São Paulo: Fundacentro, 2003.

[18]FERREIRA, Mário César. Atividade, categoria central na concepção de trabalho em ergonomia. RevistaAlethéia, 1, (11), 2000.

[19] GARRIGOU, Alain; DANIELLOU, François, CARBALLEDA, Gabriel; RUAUD, S.Activity analysis in participatory design and analysis of participatory design activity. International Journal of Industrial Ergonomics, 15, (5), 1995.

[20]GARRIGOU, Alain; WEILL-FASSINA, Annie; BRUN, JeanPierre; SIX, Francis; CHESNAIS, Marion; CRU, Damien. As atividades dos profissionais de segurança: uma problemática desconhecida. In: Congresso Brasileiro de Ergonomia, 9, Salvador. Anais... Salvador, 1999

[21] GOMES, José Orlando; CARVALHO, Paulo V. R.; WOODS, David D.; BENCHEKROUN, TaharHakim; BORGES, Marcos R. S. Resiliência e Fragilidade dos Sistemas de Trabalho e Sustentabilidade: estudos de casos de sistemas sócio-técnicos complexos no Brasil na área nuclear, aviação e emergência. Laboreal, 5, (1), 2009

[22] GUÉRIN, François; LAVILLE, Antoine; DANIELLOU, François; DURAFFOURG, J.; KERGUELEN, A Compreender o trabalho para transformá-lo: a prática da ergonomia. São Paulo: EdgardBlücher, 2001.

[23] HALE, Andrew; HEIJER, Tom. Defining resilience. In: HOLLNAGEL, Erik; WOODS, David D.; LEVERSON, Nan- cy (Org.). Resilience engineering: concepts and precepts. Aldershot: Ashgate, 2006

[24]LAVILLE, Antonie. Ergonomia. São Paulo: EPU, 1977, 101p. [Tradução Márcia Maria Neves Teixeira]

[25]LAVILLE, Antonie. Referências para uma história da ergonomia francófona. In: FALZON, Pierre (Org.). Ergonomia. São Paulo: EdgardBlücher, 2007.

[26]LEPLAT, Jaques. Aspectos da complexidade em ergonomia. In: DANIELLOU, François (Org.). A ergonomia em busca de seus princípios: debates epistemológicos. São Paulo: EdgardBlücher, 2004.

[27]LIMA, Francisco de Paula Antunes; RESENDE, Adson Eduardo; VASCONCELOS, Renata Campos. Condicionantes sociais do projeto de instrumentos de trabalho: o caso de uma bancada de inspeção. Produção, 19, (3), 2009.

[28]LIMA, Francisco de Paula Antunes; SILVA, Carlos Alberto Diniz. A objetivação do saber prático na concepção de sistemas especialistas: das regras formais às situações de ação. In: DUARTE, Francisco (Org.). Ergonomia e projeto na indústria de processo contínuo. Rio de Janeiro: Lucerna, 2002.

[29]LOVE, Terence. Design as a social process: bodies, brains and social aspects of designing. Journal of Design Research, $3,(1), 2003$

[30]LLORY, Michel. Fiabilitéetsécuritéorganisationnelles: diagnostic organisationnel. Performances, 2, 2002.

, Edgar. Introduction à la penséecomplexe. Paris: ESP Éditeur, 1990.

[31] PARIÈS, Jean. Complexity, emergency, resilience... In: Hollnagel, Erik; WOODS, David D. e LEVESON, Nancy (Org.). Resilience Engineering: Concepts and Precepts. Aldershot: Ashgate, 2006

[32]REICH, Yoram; KONDA, Suresh L.; MONARCH, Ira A.; LEVY, Sean N.; SUBRAHMANIAN, Eswaran. Varieties and issues of participation and design. Design Studies, 17, (2), 1996.

[33] ROGALSKI, Janine. A gestão de riscos. In: FALZON, Pierre (Org.). Ergonomia. São Paulo: EdgardBlücher, 2007.

[34] SANDERSON, Penelope M. The human planning and scheduling role in advanced manufaturing systems: na emerging human factors domain. Human factors, 31, (6), 1989.

[35] SILVA, João Alexandre Pinheiro; BRAATZ, Daniel; MENEGON, Nilton Luiz; CARVALHO, Marly Monteiro de; CAMAROTTO, João Alberto. Inovação e participação: um estudo de caso de projeto de uma interface para painel de controle de equipamento. In: Congresso Brasileiro de Ergonomia - ABERGO, 15. Porto Seguro. Anais... Porto Seguro, 2008

[36] TERSAC, Gilbert de; MAGGI, Bruno. O trabalho e a abordagem ergonômica. In: DANIELLOU, François (Org.). A ergonomia em busca de seus princípios: debates epistemológicos. São Paulo: EdgardBlücher, 2004.

[37] WISNER, Alain. A antropotecnologia. Estudos avançados, 6, (16), 1992

[38] WISNER, Alain. Questões epistemológicas em ergonomia e em análise do trabalho. In: DANIELLOU, François (Org.). A ergonomia em busca de seus princípios: debates epistemológicos. São Paulo: EdgardBlücher, 2004.

[39] WISNER, Alain. Understanding problem bulding: ergonomic work analysis. Ergonomics, 38, (3), 1995

[40] WOODS, David D; COOK, Richard I. Incidents - markers of resilience or brittleness? In: HOLLNAGEL, Erik; WOODS, David D.; LEVERSON, Nancy (Org.). Resilience engineering: concepts and precepts. Aldershot: Ashgate, 2006.

[41] WOODS, David D; HOLLNAGEL, Erik. Prologue: resilience engineering concepts. In: Hollnagel, Erik; WOODS, David D. 
e LEVESON, Nancy (Org.). Resilience Engineering: Concepts and Precepts. Aldershot: Ashgate, 2006

[42] WREATHALL, John. Properties of resilient organizations: an initial view. In: HOLLNAGEL, Erik; WOODS, David D.

LEVERSON, Nancy (Org.). Resilience engineering: concepts and precepts. Aldershot: Ashgate, 2006. 